\title{
Potential Land Development for Arabica Coffee in Sungai Penuh, Jambi Province
}

\author{
Fadhel Geshana Putra ${ }^{1}$, Iwan Rudiarto ${ }^{2}$ \\ \{fadhelgeshanaputra@gmail.com ${ }^{1}$, irudiarto@yahoo.com² $\}$
}

${ }^{1}$ Development Planning Agency at Sub-National Level, Sungai Penuh City, Jambi, Indonesia

${ }^{2}$ Department of Urban and Regional Planning, Diponegoro University, Semarang, Indonesia

\begin{abstract}
Regional Development in the long term is more emphasized on the potential introduction of natural resources and regional development. As one of the cities that has abundant natural resource potential, Sungai Penuh City should optimize its potential of coffee cultivation. This plant commodity is viewed by the government as a potential to improve the welfare of its people as well as to keep nature sustainable. This study aims to determine land that has the potential land for coffee plantation by using overlay analysis in GIS. The methods used in this study are the Agro-Ecological Zone (AEZ) analysis and land suitability analysis. The variables consist of physiographic, slope, altitude, soil type, rainfall, protected forest and map of existing conditions. The potential land for Arabica coffee, is the result of overlaying the AEZ and land suitability. The results is 1,346 hectares could potentially be planted with arabica coffee plants.
\end{abstract}

Keywords: Agro-Ecological Zone, coffee plantation, spatial planning, Land suitability.

\section{Introduction}

Indonesia is one of the countries with the highest coffee consumption in the world. International Coffee Organization (ICO) recorded Indonesian coffee consumption in the 20162017 reached 4.6 million packages of $60 \mathrm{~kg} / \mathrm{lb}$ and in the 6th position with the highest coffee consumption in the world after Russia. According to Indonesian Plantation Statistics, from 2014 to 2016, the largest coffee producer in the world is Brazil. Indonesia is also one of the largest coffee producers in the world, with production reaching 639 thousand tons in 2016 with the aim of exports being the United States [1].

Sungai Penuh city is categorized as an Agropolitan city. Hasan (2003) suggested that agropolitan city activities are based on agricultural cultivation, conservation of natural resources and development of regional potential with an environmentally sound development framework [2]. One of the local product potentials in this region is coffee plantations, which is also a leading commodity that can improve the region's economy. Sungai Penuh City is also promoted as a Regional Activity Center (PKWp) to cover up the provincial-scale activities or several districts that have roles and functions as government centers, tourism service centers, education, and conservation areas. According to Soemarno (2011), the knowledge of the properties and characteristics of the correct land agroecology is the basis of efforts to develop commodities and agricultural development towards sustainable development policies [3].

The development of coffee plantations in Sungai Penuh City has been carried out for around eight years and, physically, has shown a high increase. Sungai Penuh is geographically supporting the Arabica coffee plantation. From 2008, the total coffee plantation area increased to 601 ha in 2017. According to BPS data in 2018, currently, there is $999 \mathrm{Ha}$ in Sungai Penuh 
City from 1,600 ha of potential coffee plantations. However, according to Bomberdin, around 964 hectares are still unused land [4]. By looking at the potential and problems faced, it is necessary to research the development of agro-industries in Sungai Penuh City.

This study aims to determine the potential location of coffee plantations based on land suitable analysis and AEZ analysis. This research is useful as an input for facilitating decision making, planning, assessment, and development of superior spatial commodities. Many types of research on potential agricultural land have been carried out, including by Pilehforooshha et al. With the aim of research to produce maps of agricultural land use, the output can be used to develop agricultural land use plans adapted to other areas by adapting factors depending on local conditions [5]. This study did not specifically assess the potential land for coffee plants, but the method used to determine potential land could be applied in this study. The previous study by Nugraha et al. about Determining Potential Locations for the Development of Industrial Estates, the study aims to develop industrial zones divided into five classes using geographic information systems [6]. The study more specifically examines the division of potential industrial land classes, but in the method of potential class distribution of land can be applied to the determination of potential coffee land classes in this study. AEZ analysis can help in determining the land use and requires a relatively short time. So that the potential of the region can be optimized and efforts to conserve natural resources can be managed wisely. land suitability analysis is used to sharpen the results of the previous analysis to produce a more detailed and specific output. For the wider benefits, this analysis can be used as a basis for determining spatial planning.

\section{Research Method}

This research is located in Sungai Penuh City, This area is located in Kerinci Seblat National Park (TNKS) area with an altitude of 500 to 1500 masl. The type of soil is dominated by andosols and latosols, with a wet climate, average air temperature of $22.9^{\circ} \mathrm{C}$, and annual rainfall $\pm 1800 \mathrm{~mm}$. According to BPS data in 2018, the population of Sungai Penuh City in 2017 was 88,918 people with a population density of 224 / km, and the population growth rate from $2010-2015$ was $5.46 \%$ per year.

Identification of arabica coffee plants in Sungai Penuh City was carried out through image interpretation. The identity and type of object depicted in the image is an essential part of image interpretation. The principle of recognizing an object on the image is based on the characteristics of the attribute in the image. The characteristics of the objects depicted in the image are identified using 8 (eight) elements of interpretation, namely hue or color, size, shape, texture, pattern, shadow, location or site, and association of object appearance. The elements of interpretation are arranged in stages to facilitate the introduction of objects in the image. The arrangement is based on the level of complexity in object recognition [7]. Based on image interpretation can be made a map of the distribution of coffee plants in Sungai Penuh City.

Compilation of this research is the determination of the data variable that is suitable with the physical conditions. The data used is obtained using primary data obtained from the surveys and secondary data obtained from relevant agencies. The use of multivariable data requires weighing between variables. From the results of the scoring, the indicators were then arranged as a reference in the preparation of the overlay analysis. Indicators for determining potential land for Arabica coffee plants are presented in Table 1 
Table 1. Indicators for Determining Potential Land for Arabica Coffee Plants

\begin{tabular}{|c|c|c|c|c|c|c|c|c|c|c|}
\hline \multirow{3}{*}{ No } & \multicolumn{8}{|c|}{ Zone Grouping } & \multirow{3}{*}{ score } & \multirow{3}{*}{ Zone } \\
\hline & \multicolumn{2}{|c|}{ Slope } & \multicolumn{2}{|c|}{ Altitude } & \multicolumn{2}{|c|}{ Type of soil } & \multicolumn{2}{|l|}{ Physiography } & & \\
\hline & Data & Score & Data & score & Data & score & Data & Score & & \\
\hline 1 & $\begin{array}{c}>40 \\
\%\end{array}$ & 25 & $\begin{array}{c}>1250 \\
\text { masl }\end{array}$ & 25 & alluvial & 25 & Steep slope & 25 & $\begin{array}{l}81- \\
81\end{array}$ & I \\
\hline 2 & $\begin{array}{l}16- \\
40 \%\end{array}$ & 20 & $\begin{array}{c}750< \\
1250 \\
\text { masl }\end{array}$ & 20 & latosol & 20 & $\begin{array}{c}\text { hilly- } \\
\text { mountainous }\end{array}$ & 20 & $\begin{array}{l}61- \\
80\end{array}$ & II \\
\hline 3 & $\begin{array}{c}8- \\
15 \%\end{array}$ & 15 & $\begin{array}{c}500- \\
750 \\
\text { masl }\end{array}$ & 15 & podzolic & 15 & wavy & 15 & $\begin{array}{l}41- \\
60\end{array}$ & III \\
\hline 4 & $<8 \%$ & 10 & $\begin{array}{l}<500 \\
\text { masl }\end{array}$ & 10 & andosol & 10 & flat-wavy & 10 & $\begin{array}{c}21- \\
40\end{array}$ & IV \\
\hline 5 & $<3 \%$ & 5 & $\begin{array}{l}<500 \\
\text { masl }\end{array}$ & 5 & organosol & 5 & $\begin{array}{l}\text { Swamps and } \\
\text { peatlands }\end{array}$ & 5 & $0-20$ & $\mathbf{V}$ \\
\hline Weight & \multicolumn{2}{|l|}{$25 \%$} & \multicolumn{2}{|l|}{$25 \%$} & \multicolumn{2}{|l|}{$25 \%$} & \multicolumn{2}{|l|}{$25 \%$} & & \\
\hline
\end{tabular}

Determination of agro-ecological zones is carried out by first assessing the components of the physical environment. Based on the results of overlaying maps of land resources, climate and land use of Sungai Penuh City, 5 (five) agro-ecological zones (AEZ) were obtained. Agroecological zone with detailed specifications of the Sungai Penuh city agricultural type system as follows [8]:

Zone I: $\quad$ Zone I is a zone with land-use types for protected areas (conservation). This area covers lowland to mountainous areas with an altitude of 1550masl, zone with slopes $>40 \%$.

Zone II: This zone is a zone with the type of plantation land use/cultivation of annual crops/fruits. This zone is at an altitude of $<1250$ masl with high temperatures, with slopes of $16-40 \%$, land use types for plantations (annual crops). The types of commodities suitable for plantations or annual crops in this zone are cocoa, coffee, rubber, and kapok.

Zone III: This zone is a zone with the direction of the use of agroforestry or agroforestry land. Wavy physiography with slopes ranging from $8-15 \%$, the choice of plant species such as peanuts, soybeans, green beans, sweet potatoes, taro, and cassava can be planted between perennials or cacao, coffee, oil palm, matoa, rambutan, duku and others as permanent plants.

Zone IV: This zone is a zone with land use directions for dryland farming both food crops and lowland horticulture. Slope zone $<8 \%$, its use for dryland agricultural.

Zone V: This zone is a zone with a slope class $<3 \%$ in the form of swamps or peatlands with a thickness of $>1.5 \mathrm{~m}$. Alternative utilization directions are for wetlands and fisheries.

The next stage the researcher conducts land suitability analysis by producing more accurate output, Land suitability analysis is carried out based on the method set by FAO (Food and Agriculture Organization). In classifying land suitability, the 1976 FAO framework divides the classification structure into four categories of orders, classes, sub-classes, and units [9]. This analysis is a method modification carried out in Pariamanda's research, s. in her research with the aim of determining coffee potential land in Semarang district by using land 
suitability analysis [10]. The variable is the altitude, type of soil, rainfall, and slope [11]. This study adopting her method but there are several modification variables, the determination of land suitability analysis in this study is proteocted forest. most of the Sungai Penuh city is included in protected forests (national Kerinci Seblat park). The land suitability criteria for each parameter used in this study can be seen in Table 2.

Table 2. Grouping Classes of Arabican Coffee Potential Lands

\begin{tabular}{|c|c|c|c|c|c|c|c|c|c|c|c|c|}
\hline \multirow{3}{*}{ No } & \multicolumn{10}{|c|}{ Grouping Land Suitability Classes } & \multirow{3}{*}{$\begin{array}{l}\text { Total } \\
\text { Score }\end{array}$} & \multirow{3}{*}{ class } \\
\hline & \multicolumn{2}{|c|}{ Slope } & \multicolumn{2}{|c|}{ Altitude } & \multicolumn{2}{|c|}{ Type of Soil } & \multicolumn{2}{|c|}{ Rainfall } & \multicolumn{2}{|c|}{$\begin{array}{c}\text { Protection } \\
\text { Forest } \\
\text { (TNKS) }\end{array}$} & & \\
\hline & Data & $\mathrm{S}$ & Data & S & Data & $\mathrm{S}$ & Data & $S$ & Data & S & & \\
\hline 1 & $>30 \%$ & 1 & $>2000$ & 1 & $\begin{array}{l}\text { latosol } \\
\text { aluvial }\end{array}$ & 4 & $<1500$ & 4 & $\begin{array}{l}\text { Non } \\
\text { tnks }\end{array}$ & 4 & 13-16 & S1 \\
\hline 2 & $16-30 \%$ & 2 & $\begin{array}{l}1750< \\
2000\end{array}$ & 2 & $\begin{array}{c}\text { Podsolik } \\
\text { Glei humus }\end{array}$ & 3 & $\begin{array}{c}1500- \\
2500\end{array}$ & 3 & tnks & 1 & $9-12$ & S2 \\
\hline 3 & $8-15 \%$ & 3 & $\begin{array}{c}1600- \\
1750\end{array}$ & 3 & Organosol & 2 & $\begin{array}{c}2500- \\
4000\end{array}$ & 2 & tnks & 1 & $5-8$ & S3 \\
\hline \multirow[t]{2}{*}{4} & $<8 \%$ & 4 & $700-1600$ & 4 & andosol & 1 & $>4000$ & 1 & tnks & 1 & $0-4$ & $\mathbf{N}$ \\
\hline & \multicolumn{2}{|l|}{$25 \%$} & \multicolumn{2}{|l|}{$25 \%$} & \multicolumn{2}{|l|}{$25 \%$} & \multicolumn{2}{|c|}{$25 \%$} & \multicolumn{2}{|c|}{$25 \%$} & \multicolumn{2}{|c|}{ Weight } \\
\hline
\end{tabular}

According to Djali and Pudji (2008), Evaluation can be interpreted as a process of assessing something based on established criteria or goals which are then followed by decision making on the evaluated object [12]. Land evaluation is a process of estimating the potential of land resources for various uses [13]. Land evaluation according to Zuidam and Concelado (1979) is the process of implementing land valuation for certain needs including the interpretation of survey results and studies recognizing landforms, land, land use, vegetation, climate, and other aspects to identify and compare land use for evaluation purposes [14]. Land Evaluation To determine the method and approach needed, the basics must be determined in advance, Which includes the following provisions: Land suitability must be based on land use for a particular purpose, Because different uses require different conditions. The evaluation includes more than one type of land use or needs comparison[13]. Purpose of Evaluation According to FAO (1976) the purpose of the evaluation is to determine the value of land for certain purposes, the step in evaluating land after setting a goal is to determine the characteristic factors. This factor is the nature of the land that has a close relationship with the purpose of evaluation. Every activity carried out must have a purpose, as well as evaluation. [9]

Based on these variables, an overlay analysis, scoring data, reclassify than overlay with an output of AEZ analysis, the results are then carried out. For more details can be seen in figure 1. The resulting data is then compiled into the form of spatial data information, which can then be processed into GIS software. 


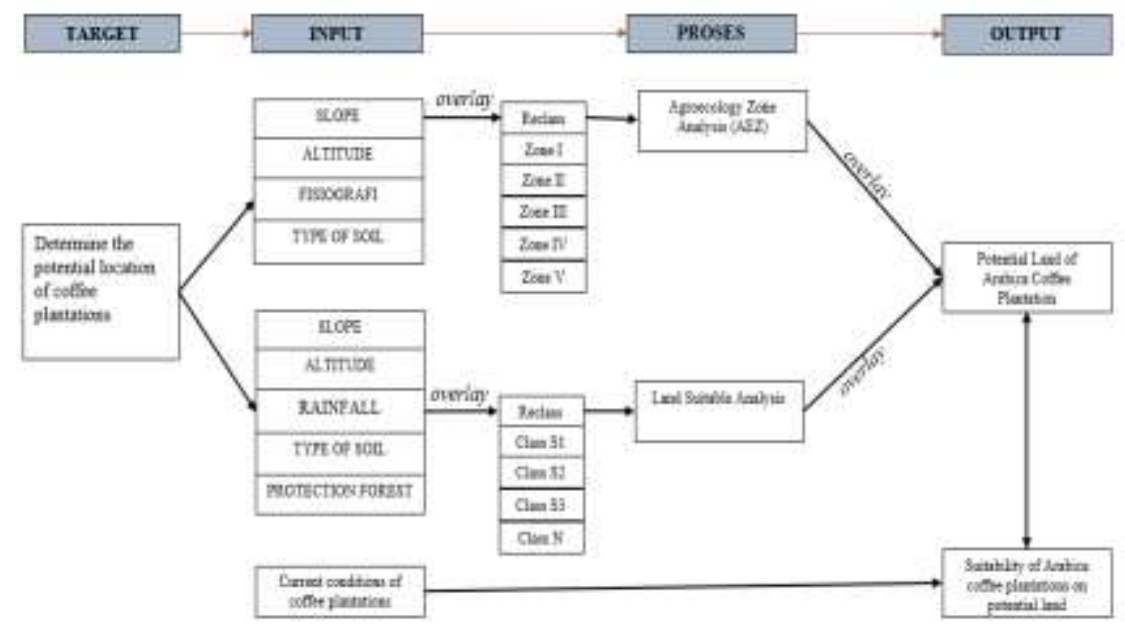

Fig.1. Analysis Framework of Potential Land for Arabica Coffee

\section{Result and Discussion}

\subsection{Agroecology Zone Analysis}

The Agro-Ecology Zone (AEZ) is a system of grouping or zoning an area based on the physical conditions of nature to determine the natural potential by the character of the region. Determination of this analysis is based on indicators of determining potential coffee plantations (Table 1). The indicator is a reference in carrying out the scoring and weighting stages using ArcGIS software. Next is the process of overlapping data or overlaying between data. The results obtained in the form of a zone I to zone V.

In this research, the mapping output is consisting zone II, zone III, zone IV and zone V. This map provides information on the suitability of land use, fertilizer recommendations, and recommendations on types of crop commodities. The results of the AEZ analysis are presented in Fig 2.

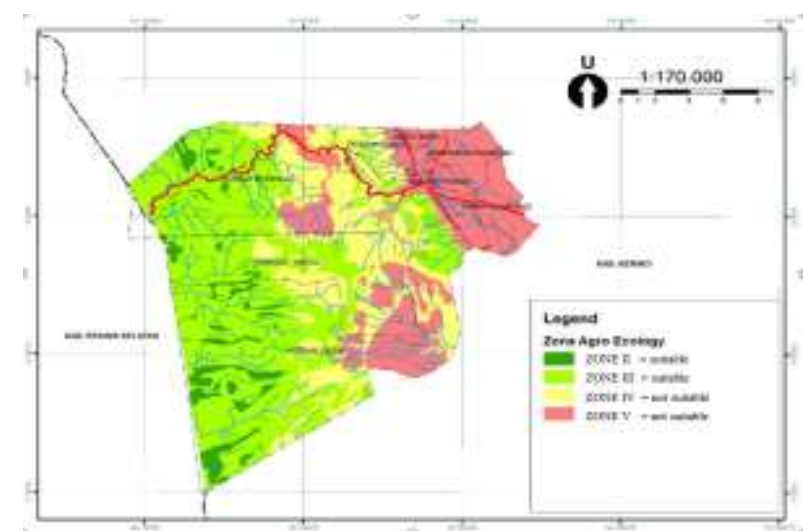

Fig. 2. Map of the Agro Ecological Zone in Sungai Penuh City 
The mapping output is consisting zone II, zone III, zone IV and zone V. The calculation of AEZ analysis, it was found that the land area and location of potential land for Arabica coffee plants in zone II and zone III totaled 18.321,3 ha. Based on the map above, There are some potential lands for planting Arabica coffee in several sub-districts, namely Kumun Debai, Pondok Tinggi, Sungai Bungkal and Pesisir Bukit. The most extensive potential of Arabica is the Kumun Debai sub-district with an area of 9.622 ha. According to AEZ's analysis in this zone, it is very suitable to use for plants such as coffee, cocoa, rubber and kapok. For more details on the potential area of the commodity based on AEZ's analysis can be seen in table 3 below:

Table 3. Potential Zone for Arabica Coffee

\begin{tabular}{|c|l|c|c|c|c|}
\hline \multirow{2}{*}{ ZONE } & \multicolumn{3}{|c|}{ Secommendation } & \multicolumn{4}{|c|}{ Sub - District } \\
\cline { 3 - 5 } & \multicolumn{1}{|c|}{ SB } & KD & PT & PB \\
\hline II & $\begin{array}{l}\text { plantations (cocoa, coffee, rubber and } \\
\text { kapok.) }\end{array}$ & 324,7 & $1.258,3$ & 188,9 & - \\
\hline III & $\begin{array}{l}\text { Peanuts, soybeans, sweet potatoes, } \\
\text { perennials or cacao, coffee, others as } \\
\text { permanent plants }\end{array}$ & $5.071,6$ & $8.363,7$ & $2.988,6$ & 125,5 \\
\hline TOTAL & \multicolumn{2}{|c|}{$5.396,3$} & 9.622 & $3.117,5$ & 125,5 \\
\hline
\end{tabular}

$S B=$ Sungai bungkal, $K D=$ kumun debai, $P T=$ pondok tinggi, $P B=$ Persisir bukit

\subsection{Suitable Land Analysis}

Potential land suitability is the suitability given input of improvement or conservation on the parameters which are limiting factors [15]. The analysis is based on indicators of determining potential coffee plantations (Table 2). Indicators are references in conducting the assessment and weighting stages using ArcGIS software. Next is the process of overlapping data or overlaying between data. The results obtained in the form of S1 class, S2 class, S3 class and class N. The results of land suitability analysis are presented in Figure 3.

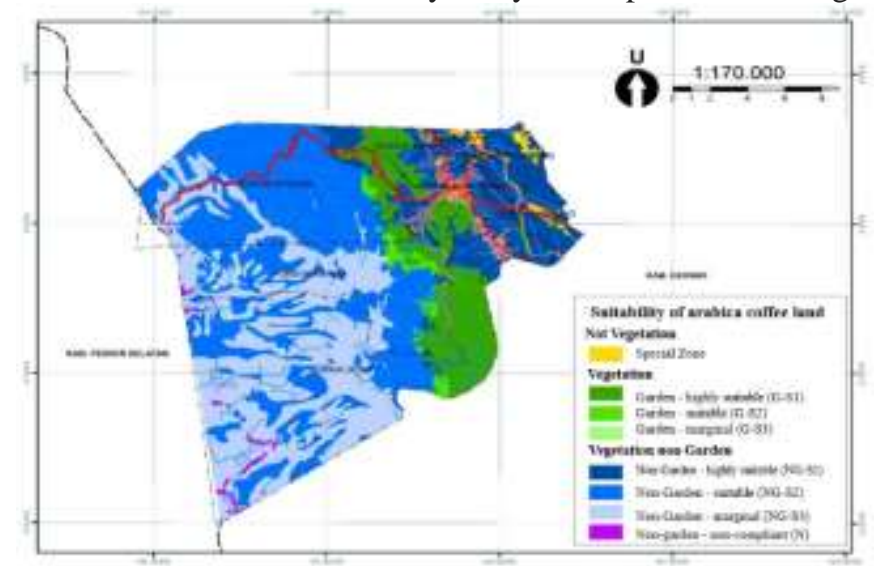

Fig. 3. Map of Potential Coffee Land Based on Suitable Land Analysis

This analysis is done by matching the suitability of the parameters used with the criteria for the coffee plant criteria. Next is the selection of the results of the land suitability class. The 
land suitability class in an area is determined based on the type of land use. In this analysis several categories of land suitability classes were obtained, namely: garden - highly suitable (G-S1), garden - suitable (G-S2), garden - marginal (G-S3), non-garden - highly suitable (NGS1 ), non-garden - suitable (NG-S2), non-garden - marginal (NG-S3), non-garden - noncompliant (N) and Special zone (SZ). Garden land is included in plantation areas. Non-Garden are land which includes rice fields, bushes, and forests. While special zones other than vegetation can be either built up or swampland. Special zones are zones that can no longer be converted into coffee plantations based on land use maps consisting of irrigated rice fields, forests, public facilities, rainfed, settlements, villages and land emplacement. The purpose of the plantation in this study is land that can be used as a garden and has a suitable land for planting coffee plants. Further explanation will be explained in the table below:

Table 4. potential land area per sub-district in total

\begin{tabular}{|c|c|c|c|c|c|c|c|c|c|}
\hline \multirow[b]{2}{*}{ No } & \multirow[b]{2}{*}{ District } & \multicolumn{8}{|c|}{ Land Area (Ha) } \\
\hline & & $(\mathrm{G}-\mathrm{S} 1)$ & (G-S2) & $\begin{array}{l}\text { (G- } \\
\text { S3) }\end{array}$ & $\begin{array}{c}\text { (NG- } \\
\text { S1) }\end{array}$ & (NG-S2) & $\begin{array}{c}\text { (NG- } \\
\text { S3) }\end{array}$ & $(\mathrm{N})$ & $(\mathrm{SZ})$ \\
\hline 1 & $\begin{array}{l}\text { Hamparan } \\
\text { Rawang }\end{array}$ & - & - & - & 923,84 & - & - & - & $\begin{array}{l}270,9 \\
3\end{array}$ \\
\hline 2 & Koto Baru & - & - & - & 118,87 & - & - & - & 38,15 \\
\hline 3 & Kumun Debai & 1758,8 & 120,23 & - & 1114,87 & 3886,81 & $\begin{array}{l}7523,8 \\
6\end{array}$ & 185,13 & $\begin{array}{l}119,3 \\
2\end{array}$ \\
\hline 4 & Pesisir Bukit & 563,28 & - & - & 927,23 & 102,83 & - & - & $\begin{array}{l}108,3 \\
0\end{array}$ \\
\hline 5 & Pondok Tinggi & 1241,2 & 365,25 & 5,72 & 626,90 & 2482,26 & $\begin{array}{l}2488,4 \\
2\end{array}$ & 22,15 & $\begin{array}{l}160,0 \\
8\end{array}$ \\
\hline 6 & Sungai Bungkal & 741,55 & 116,95 & - & 636,55 & 6187,06 & $\begin{array}{l}1320,4 \\
4\end{array}$ & 6,70 & $\begin{array}{l}113,5 \\
6\end{array}$ \\
\hline 7 & Sungai Penuh & 0,74 & - & - & 238,62 & - & - & - & 75,84 \\
\hline 8 & Tanah Kampung & 47,19 & - & - & 912,88 & - & - & - & $\begin{array}{l}151,6 \\
0\end{array}$ \\
\hline & Total & 4353 & 602 & 5,72 & 5499,76 & 12.659 & 11.333 & 213,9 & 1.038 \\
\hline
\end{tabular}

$g=$ garden, $n=$ non, $s z=$ special zone

The table above shows that the land that is highly recommended in Arabica coffee management in the Sungai Penuh city is in the G-S1 and G-S2 classes. The total potential land of arabica coffee in the Sungai Penuh city is 4,955.2 ha. Based on the two analyzes. The potential land that has the highest suitability and score is in the suitability of S1 in zone III with a total area of 1,346.52 Ha. Potential land of arabica coffee is in the Kumun Debai subdistrict, Pesisir Bukit, Pondok Tinggi and Sungai Bungkal it can be seen in figure 4 below: 


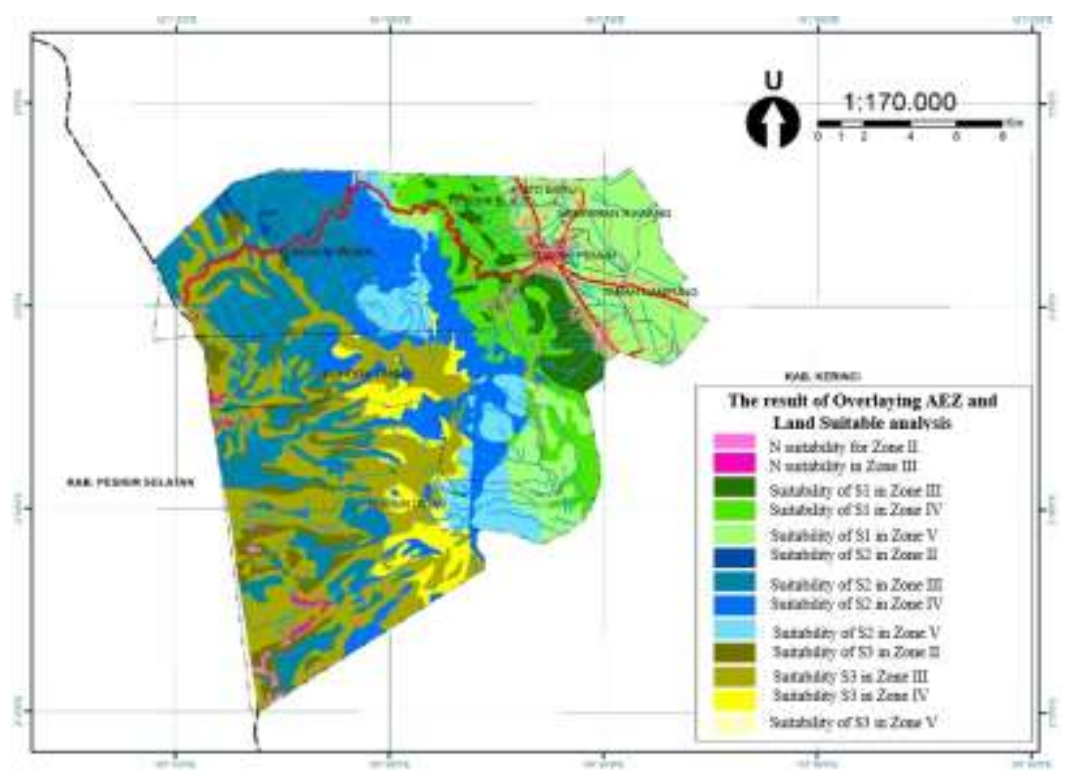

Fig. 4. Map of Coffee Potential Land

The results obtained after knowing the land that has the potential in a Sungai Penuh city are overlaying the existing map of Arabica coffee in the Sungai Penuh city. The results of this analysis will find out how wide the actual coffee grows on potential land and how much area that grows does not fit in its place. Then the results obtained are in figure 5 below:

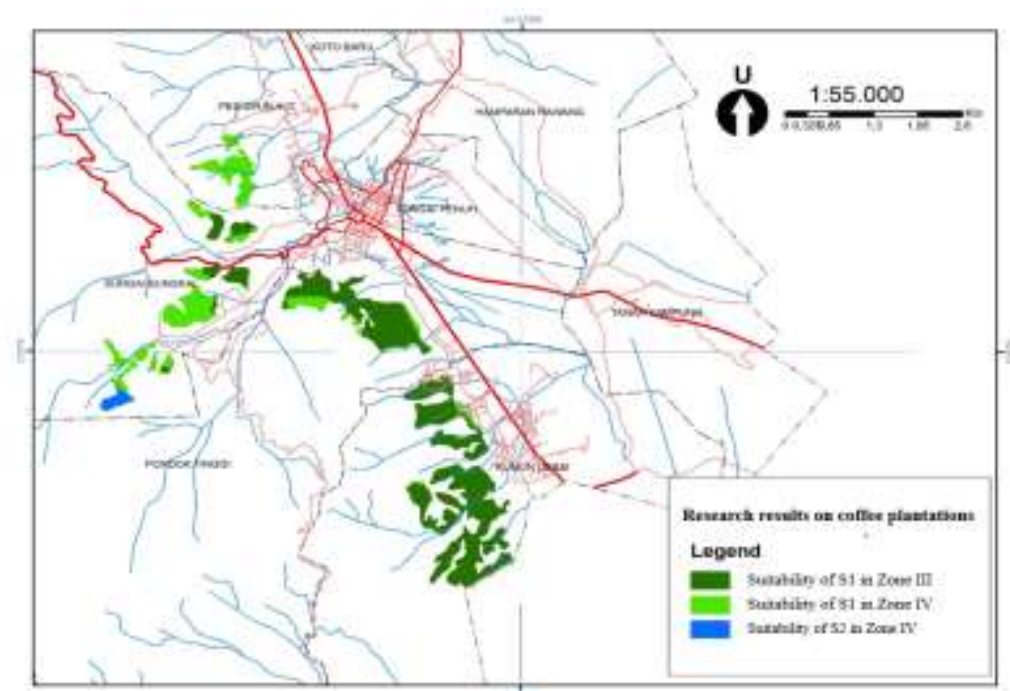

Fig. 5. Existing Condition Map of Arabica Coffee Plantation in Land Potential

The result of map above that arabica coffee is found in potential land is 318.91 ha which in the suitability of S1 and zone III. The rest is the land suitability S1 zone IV and suitability of land S2 zone IV which can also be planted with arabica coffee. 


\section{Conclusion}

The agricultural area in the Sungai Penuh city can be divided into 4 agroecological zones, namely Zone II, Zone III, Zone IV, and Zone V. the largest zone is zone III (around 16 thousand ha), hill and mountain sloping 8-15\% , 500-2000 masl, and soils in general alluvial, andosol, latosol, and podzolic categories. Each zone has different agricultural potential. Around 18.321,3 hectares still have the potential to be used as Arabica coffee plantations. At present, land use for Zone II is still not optimally managed, because it is still used as a dry land crop. Kumun Debai Subdistrict is the area with the widest potential. Based on the results of the AEZ analysis shows that Sungai Penuh City is dominated by Zone III.

Based on the land suitability analysis, potential land for arabica coffee is 4,955.2 ha. Consisting of garden class-highly suitable (S1) covering an area of 4,353 ha and gardenssuitable (S2) covering 602 ha. The Kumun Debai sub-district dominates and is a highly recommended sub-district for the expansion of Arabica coffee plantation in the Sungai Penuh city. The Sungai Penuh city is still at 12.1 percent planted by a coffee plantation.

The results of overlaying between the two analyzes are known that potential Arabica coffee land is very good if it is planted in S1 land suitability and in zone III with a total area of 1,346.52 ha. This land is the most recommended land for planting Arabica coffee in the Sungai Penuh city. So that it will increase productivity and in accordance with the allotment of land that is in the Sungai Penuh city spatial plan and not including a protected forest (TNKS). The existing conditions on potential Arabica coffee land that there are $70.4 \%$ of the coffee grown on potential land.

\section{References}

[1] D. J. Perkebunan, "Statistik Perkebunan Indonesia: Kopi 2014-2016.," Direktorat Jenderal Perkeb., 2015.

[2] Hasan, "Model Tata Ruang Kota Tani yang Berorientasi Ekonomis dan Ekologis (Studi Kasus di Kabupaten Gowa, Provinsi Sulawesi Selatan)," Institut Pertanian Bogor, 2003.

[3] Soemarno, "Evaluasi Lahan dan Pewilayahan Komoditi Pertanian, Perkebunan Dan Kehutanan," 2011.

[4] H. Dede, "964 Hektare Lahan Kopi di Sungaipenuh Belum Tergarap, Harga dan Daya Jual Cukup Tinggi," Jambi Tribunnews, 03-Nov-2017.

[5] P. Pilehforooshha, M. Karimi, and M. Taleai, "A GIS-based agricultural land-use allocation model coupling increase and decrease in land demand," Agric. Syst., vol. 130, pp. 116-125, 2014.

[6] W. S. Nugraha, S. Subiyanto, and A. P. Wijaya, "Penentuan Lokasi Potensial Untuk Pengembangan Kawasan Industri Menggunakan Sistem Informasi Geografis di Kabupaten Boyolali,” J. Geod. Undip, vol. 4, no. 1, pp. 194-202, 2015.

[7] Sutanto, Penginderaan Jauh Jilid 1. Jogjakarta: UGM Press, 1986.

[8] H. Kubelaborbir and K. Yarangga, "Zona Agroekologi Kabupaten Keerom Provinsi Papua Berdasarkan Pendekatan Sistem Informasi Geografis (SIG),” Agrikultura, vol. 21, no. 1, 2010.

[9] Food Agricultural Organization, "A Framework For Land Evaluation,” Soil Bulletin, Rome, 1976.

[10] S. Pariamanda, A. Sukmono, and H. Haniah, "Analisis Kesesuaian Lahan Untuk 
Perkebunan Kopi Di Kabupaten Semarang,” J. Geod. Undip, vol. 5, no. 1, pp. 116124, 2016.

[11] D. Djaenudin, A. Hidayat, and H. Suhardjo, "Petunjuk teknis evaluasi lahan untuk komoditas pertanian," 2003.

[12] P. M and Djaali, Pengukuran dalam Bidang Pendidikan. Jakarta: Grasindo, 2008.

[13] M. L. Rayes, "Metode inventarisasi sumber daya lahan," Andi. Yogyakarta, 2007.

[14] F. . van Zuidam-Cancelado and R. . Zuidam, Terrain Analysis and Classi-fication Using Aerial Photographs. A Geomorphological Approach, ITC Textbook of Photo Interpretation, VII-6. 1979.

[15] B. P. Tanah, Evaluasi Lahan Untuk Komoditas Pertanian. Pusat Penelitian dan Pengembangan Tanah dan Agroklimat. Bogor, 2011. 